\title{
"Human resource management practices and total quality management in insurance companies: Evidence from Jordan"
}

\begin{tabular}{|c|c|}
\hline \multirow{5}{*}{ AUTHORS } & Naser Khdour (D https://orcid.org/0000-0002-3044-8792 \\
\hline & Ahmad Samed Al-Adwan (D https://orcid.org/0000-0001-5688-1503 \\
\hline & $\mathbb{R}$ http://www.researcherid.com/rid/E-3546-2019 \\
\hline & Anas Alsoud (D https://orcid.org/0000-0002-1410-8843 \\
\hline & Jamal Ahmed Al-Douri (D https://orcid.org/0000-0001-6508-5373 \\
\hline ARTICLE INFO & $\begin{array}{l}\text { Naser Khdour, Ahmad Samed Al-Adwan, Anas Alsoud and Jamal Ahmed Al- } \\
\text { Douri (2021). Human resource management practices and total quality } \\
\text { management in insurance companies: Evidence from Jordan. Problems and } \\
\text { Perspectives in Management, 19(1), 432-444. doi:10.21511/ppm.19(1).2021.36 }\end{array}$ \\
\hline DOI & http://dx.doi.org/10.21511/ppm.19(1).2021.36 \\
\hline RELEASED ON & Monday, 29 March 2021 \\
\hline RECEIVED ON & Wednesday, 25 November 2020 \\
\hline \multirow[t]{2}{*}{ ACCEPTED ON } & Tuesday, 16 March 2021 \\
\hline & $(\mathrm{ccc}) \mathrm{EY}$ \\
\hline LICENSE & $\begin{array}{l}\text { This work is licensed under a Creative Commons Attribution } 4.0 \text { International } \\
\text { License }\end{array}$ \\
\hline JOURNAL & "Problems and Perspectives in Management" \\
\hline ISSN PRINT & $1727-7051$ \\
\hline ISSN ONLINE & $1810-5467$ \\
\hline PUBLISHER & LLC "Consulting Publishing Company "Business Perspectives" \\
\hline FOUNDER & LLC "Consulting Publishing Company "Business Perspectives" \\
\hline
\end{tabular}

NUMBER OF REFERENCES

57

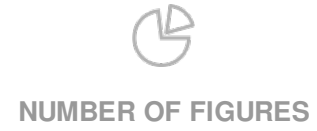

0
NUMBER OF TABLES

6

(C) The author(s) 2021. This publication is an open access article. 


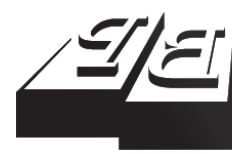

\section{BUSINESS PERSPECTIVES}

0

LLC "CPC "Business Perspectives" Hryhorii Skovoroda lane, 10, Sumy, 40022, Ukraine www.businessperspectives.org
Received on: $25^{\text {th }}$ of November, 2020 Accepted on: $16^{\text {th }}$ of March, 2021 Published on: $29^{\text {th }}$ of March, 2021

(C) Naser Khdour, Ahmad Samed AlAdwan, Anas Alsoud, Jamal Ahmed Al-Douri, 2021

Naser Khdour, Ph.D., Assistant Professor, Department of Business Administration, Business School, AL Ahliyya Amman University, Jordan. (Corresponding author)

Ahmad Samed Al-Adwan, Ph.D. Associate Professor, Department of Electronic Business \& Commerce, Business School, Al-Ahliyya Amman University, Jordan.

Anas Alsoud, Ph.D., Associate Professor, Electronic Business and Commerce Department, Al-Ahliyya Amman University, Jordan.

Jamal Ahmed Al-Douri, Ph.D., Professor, Department of Business Administration, Business School, AlAhliyya Amman University, Jordan.

This is an Open Access article, distributed under the terms of the Creative Commons Attribution 4.0 International license, which permits unrestricted re-use, distribution, and reproduction in any medium, provided the original work is properly cited.

Conflict of interest statement: Author(s) reported no conflict of interest
Naser Khdour (Jordan), Ahmad Samed Al-Adwan (Jordan), Anas Alsoud (Jordan), Jamal Ahmed Al-Douri (Jordan)

\section{HUMAN RESOURCE} MANAGEMENT PRACTICES AND TOTAL QUALITY MANAGEMENT IN INSURANCE COMPANIES: EVIDENCE FROM JORDAN

\begin{abstract}
This study aims to extend the argument about the association between HRM and Total Quality Management (TQM) in insurance companies in Jordan. It is argued that the consideration of TQM can be supported in terms of configuration as an effect of Human Resource Management (HRM) in the presence or absence of other HRM practices. Data for this study were collected from 24 insurance companies listed on the Amman Stock Exchange and 342 employees. PLS-SEM was used to analyze the data collected through path analysis. Structural equation modeling was used to examine a causal relationship between the variables. The overall effect of HRM on TQM was explored to improve quality orientation and people criteria in insurance companies. The findings have indicated a significant and positive effect of teamwork, staffing, performance appraisals, and compensation on TQM. However, training and development have a negative, but significant impact on TQM. In addition, TQM significantly and positively affects the HRM of an organization. Performance was also positively and significantly affected by HRM. TQM is an important factor of HRM in insurance companies.
\end{abstract}

\section{Keywords}

quality management, human resources, innovation, recruitment, job satisfaction, performance

JEL Classification

M10, M12, O15

\section{INTRODUCTION}

Quality management has been of great importance in operations management over the last two decades. Total quality management (TQM) offers firms a competitive advantage to improve organizational performance. According to Kafetzopoulos et al. (2015), TQM is complicated for other organizations to replicate and become a source of competitive advantage. It is important to investigate the behavior of different companies in relation to TQM implementation, including customer orientation, leadership, and human resources. Financial service organizations are affected by the global financial crisis and are making efforts to adapt to the management changes, as well as the complexity, by integrating different quality strategies for offering products and services with zero defects (Mahmutaj et al., 2015). New entrants have increased the competition in the market, and therefore, customers changed the banks or had second banking accounts as they were not satisfied with interest rates (Ullah, 2017). Organizations needed to distinguish themselves by integrating quality strategies because of high quality expectations of customers, new technology, and high competition. Different quality strategies are implemented such as business process re-engineering, total quality management, customer care, quality circles, and team building. 
Human resource management (HRM) is considered as a central element of TQM soft dimensions (Lee et al., 2015). It is the most important factor helping an organization to achieve a competitive advantage (Masa'deh et al., 2019). It is proved that HRM plays an important role in adopting TQM in an organization, despite the differences in nomenclature and different practices. Few of the previous studies have justified the HRM aspects that are likely to be managed based on the TQM principles (Khanam et al., 2016; Vaish et al., 2016). Therefore, there is a need to focus on this issue, with important challenges from prior studies that were either theoretical in nature or based on case studies. Previous studies have failed to provide coherent classification about the practices included in HRM and needed for TQM.

\section{LITERATURE REVIEW AND HYPOTHESES}

It is important to review the extant literature on HRM and TQM with a focus on specific practices and how they should be integrated to support TQM. The focus of all the HRM practices will assist managers to be conscious of the need to apply non-contradictory HRM practices for obtaining synergies, and not as separate practices in previous research. Moreover, the relationship among HRM, TQM, and performance in the context of Jordan has been emphasized in this paper to reflect the significance of the organizational personnel to obtain a competitive advantage via TQM.

The members promoting TQM in different organizational areas are included in a multidisciplinary team (Tiamaz \& Souissi, 2018). Teamwork mainly involves association between functions, customers, suppliers, managers, and non-managers, since it is essential. In the context of TQM, teamwork plays an important role in continuous enhancement of organizational functions. It allows collaborative efforts to solve quality issues, allows increase sharing of information, and facilitates cooperation to enhance group functioning. Lastly, teamwork shows strong relationship with job satisfaction; therefore, it is considered as an important TQM practice.

In traditional perspective, an organization can achieve competitive advantage by segmentation, costing, or differentiation. The first two tactics have often been regarded to be incompatible in the previous studies (Hinter-huber \& Liozu, 2017). On the contrary, cheaper and high-quality products are manufactured by implementing TQM system (Chukwulozie et al., 2018). TQM is considered as a management system comprising several dimensions that have a significant positive impact on a company's success. The diverse dimensions of TQM are used to test a direct relationship between each TQM dimension and company outcomes (Androniceanu, 2017). However, clarification is required regarding the division of TQM into different dimensions and their individual effects. TQM is characterized into hard and soft TQM (James, 2017). Moreover, intangible or behavioral factors of TQM are considered as the major influential dimensions. However, organizational performance was not associated with hard TQM dimensions.

Sophisticated selection and recruitment of techniques are required by TQM. TQM philosophy is aligned with appropriate employees' recruitment by observing their knowledge, skills, attitudes, and abilities (Madanat \& Khasawneh, 2018). It is believed that competencies and the use of multi-method selection are derived through TQM strategy. It is important to recognize the prospective employees during the recruitment process, who can work in teams, are forthcoming with concepts for enhancing procedures, have values and behaviors, and have problem-solving aptitude (Madanat \& Khasawneh, 2017).

Recruitment should be externally subjected over the internal market for fostering TQM, and supporting the participation, integration, and empowerment of an employee. Therefore, companies must allow both internal and external recruitment for evaluating TQM based on problem resolution, mathematical and statistical abilities, and technical abilities (Albuhisiand \& Abdallah, 2018). Selection has to be subjected to a more individual-centered approach as compared to a task-based selection, which allows organizational selection procedures to identify individuals who possess quality-related abilities. On the contrary, the appropriate culture should be provided during the selection procedure (Nirmala \& Faisal, 2016). The 
recruitment of employees with needed behavior and attitude provides the base for forming quality culture within an organization. Considering this, Manafi and Subramaniam (2015) stated that employees need to fit to the organizational culture that has implemented TQM system (Manafi \& Subramaniam, 2015). Lastly, job stability and TQM improvement can be confirmed through employment security.

There is major association of TQM implementation with training and development. Therefore, all the employees should receive training with appropriate quality improvement techniques (Lamine \& Lakhal, 2018). Training is an essential aspect for internal diffusion of quality practices and notions (Manhas et al., 2015). However, TQM training needs to be carried out regularly. Employee training includes the use of statistical quality control, quality control circle, practices of customer satisfaction systems, statistical quality control, and adoption of new quality concepts that is essential for many TQM programs (Singh \& Ahuja, 2015). Furthermore, employee training requires TQM tools, problem-solving techniques, and principles of TQM.

Arunachalam et al. (2018) showed that companies with ISO certification use training and development programs, unlike the companies that are not ISO certified. Professional career development with promotion opportunities for employees is considered as an extensive and continual process for TQM companies (Qasrawi et al., 2017). In addition, it needs horizontal career development based on job rotation, horizontal movement, and movement between functions. In particular, the acquisition of capabilities should allow the promotion criteria for implementing TQM.

The implementation of TQM is obstructed by traditional performance appraisal systems as it mainly focuses on individual employee, who is considered as the main contributor to organizational performance (Soltani \& Wilkinson, 2018). Quality improvements are observed by changing procedures as compared to people; therefore, performance appraisal is not aligned with TQM. Both TQM demands and employee expectations are achieved due to the critics on performance evaluation systems (Balasubramaniam \& Farooqui,
2017). Performance appraisals consider that workers are responsible for errors resulting from flaws within the system; therefore, they are disregarded (Sainiset al., 2017). On the contrary, performance appraisal based on quality performance criteria is aligned with TQM, including improvement and development goals, and offers solutions and information to existing issues (Mwalim et al., 2019). Performance appraisal must be focused on to measure group and organizational performance, even though it can be associated to individual performance (Liu et al., 2018). A 360-degree appraisal can characterize appraisal systems for TQM, with a low degree of formality, leadership practices, and major emphasis on systems, teams, and individual jobs. It has been argued that improved total quality performance is facilitated by formal performance evaluation systems (Gupta et al., 2017). However, fostering TQM within companies needs a non-traditional appraisal system. Performance appraisal is needed to train employees, develop opportunities, and conduct a formal assessment.

Compensation or incentive plans have been a critical problem in the quality management (Chang et al., 2010). Pay incentives are important based on recognition as compared to reward. In addition, cooperation and teamwork might be inhibited by individual incentives to promote internal strife (Jung et al., 2009). On the contrary, it is essential to align the TQM and reward system. In particular, employees should be compensated for cooperating, teamwork, and individually oriented compensation (ChyeKoh et al., 2004). The compensations must be based on quality criteria, which highlight equity among employees. Furthermore, output related compensation systems are required for TQM to focus on training and personal development (Cao et al., 2000). Lastly, compensation must allow financial and non-financial rewards to promote continuous recognition.

Chandler and McEvoy (2000) have found the effectiveness of a TQM strategy when stimulated by substantial group-based and training-based incentive compensation. This finding is discussed with respect to the current debate in the field regarding effective practice versus fit models of business strategy and HRM. Wickramasinghe (2012) has indicated that organizations initiate process improvement initiatives by upgrading the role of 
HR function throughout the HR department, and by redesigning HRM practices of competence development, rewards and recognition, HR planning, satisfaction and well-being, recruitment and selection, and career planning to boost TQM strategies.

Yang (2006) has confirmed that TQM practices are significantly affected by HRM. A positive impact of HRM practices has been identified on the integration of TQM. Employee and customer satisfaction can be significantly affected by the implementation of HRM practices. Moreover, corporate image and employees' quality awareness can be positively affected by the implementation of TQM practices. Perdomo-Ortiz et al. (2009) have claimed a direct and significant association, and potential moderating impact of strategic orientation towards innovation. The study has also found a direct association between positive effects of team work and technological development. Hart and Schlesinger (1991) have assumed that the human resource function staff should lead quality efforts of the company, and evaluated the performance of their own function with the implementation of Malcolm Baldrige National Quality Awards framework.

Several practitioners and academics have argued that congruence and synergy are important among HRM practices for the TQM implementation (Ruiz et al., 2019). Theoretically, it is stated that HRM practices focus on individual practices, such as recruiting, compensation, and training, and are not associated with TQM programs. The new HRM approaches include designing and implementation of consistent policies and practices to assure the human capital of a firm plays its role in achieving business objectives. The successful integration of TQM into HRM required a specific approach. Therefore, HR systems should be aligned with an organization and its quality goals. In organizations, communication, commitment to work, empowerment, teamwork can be improved by combining HRM policies with a TQM orientation. This approach has been neglected since years, despite the HRM significance in the TQM system (Masum et al., 2018). Previous studies, mostly case studies or theoretical papers, have been managed with TQM principles. Therefore, the study has mainly emphasized the discrete practice of HRM that includes appraisal or training and compensa- tion. The study has presented arguments regarding the alignment of HRM practices in a TQM system to understand the complete set of HRM practices being implemented in a TQM system.

This study contributes to the previous literature by examining the relationship between HRM, TQM, and firm performance in Jordan. A number of studies have discussed how some HRM topics must be discussed with respect to TQM principles (Ruiz et al., 2019; Androniceanu, 2017). This study emphasizes this issue, but with essential differences from previous evidence. Firstly, majority of the current research is of a theoretical nature or depends on case studies. The core limitation in these studies is that they do not offer a cohesive classification or a comprehensive outline of the HRM practices that are required for TQM. This study incorporates a previous framework to test a model of HRM for TQM. There is comparatively minimal empirical evidence that examines this issue, excluding case studies. The objective of the case study is not statistical generalization, even though it is appropriate when the objective is to establish theory in the preliminary stages of a research study or to integrate new insights to previous research. This study advances research into HRM and TQM by utilizing a methodology that will facilitate generalization. Lastly, it is argued that the emphasis of this problem must be contemplated from an organizational perspective, since the effect of a specific HRM practice on TQM is relied on the absence or presence of other HRM practices. The paucity of empirical evidence in this study has only examined a single HRM practice such as performance appraisal (Soltani et al., 2006) or training and compensation (Chandler \& McEvoy, 2000) on most occasions. Therefore, this study expands the knowledge of this relationship and makes several contributions.

The aim of this study is to determine quality orientation in the light of HRM practices that allows the adoption of TQM in insurance companies in Jordan. The study is likely to play an important role in advancing the knowledge about the association between HRM and TQM. At first, the study mainly discusses the existing literature on HRM-TQM, with the major emphasis on the practices of TQM and ways of its implementation in HRM. These results would be helpful to manag- 
ers to assist them in the application of HRM practices and obtain synergies. The study also justifies the significance of the organizational employees to achieve competitive advantage by focusing on the association between TQM, HRM, and performance. Further, the study addresses the problems related to the issues of HRM practices and the effect of such issues on insurance organizations by conducting huge critical appraisal as no extensive study has been undertaken on this subject of interest. It might be beneficial to researchers, managers, entrepreneurs, and policy makers in making serious efforts to establish HRM in insurance organizations. Lastly, the use of methodology stimulates the opposite results, allows statistical generation with other territories and samples, and reveals the empirical importance of a soft TQM dimension. In addition, all the hypotheses of the model are investigated using structural equation modeling. Based on the aforementioned discussion, the following hypotheses are proposed:

\section{$H_{1}$ : There is a statistically significant impact of teamwork on TQM.}

$H_{2}$ : There is a statistically significant impact of staffing on TQM.

$H_{3}: \quad$ There is a statistically significant impact of training and development on TQM.

$\mathrm{H}_{4}$ : There is a statistically significant impact of performance appraisals on TQM.

$H_{5}: \quad$ There is a statistically significant impact of compensation on TQM.

$H_{6}: \quad$ There is a statistically significant impact of TQM on HRM.

$H_{7}: \quad$ There is a statistically significant impact of $T Q M$ on performance.

\section{METHODS}

\subsection{Study design}

The study has used a descriptive causal design to detect the impact of TQM dimensions on the HRM practices.

\subsection{Study participants}

Insurance companies were targeted as population of this study. According to the Middle East Insurance Review (2019), there are a total of 24 insurance companies operating in the market, out of which 23 companies are listed on the Amman Stock Exchange. These companies constituted the population of the study. Data was collected from top management of quality management and human resources departments. A total of 3,124 employees are currently working in the Jordanian insurance sector, as per the Jordan Insurance Federation (2018). Therefore, a total of $789 \mathrm{em}-$ ployees were approached initially by means of a personal interview and collected data using a structured questionnaire. However, the final sample of 342 employees was determined based on the usable questionnaires received, with the response rate of $43.9 \%$. Most of the participants included in the study hold a strong position in their companies in both quality management and human resources departments.

\subsection{Study tool}

The study considered a total of 33 HRM practices characterized as TQM improvers. The most significant areas of HRM, including teamwork, career management, compensation and performance appraisal, training, job design, and staffing, are covered by these practices. All these practices were measured using a five-point Likert-type scale, ranging from strongly agree to strongly disagree. The dimensions of TQM, including continuous improvement, control, and supplier's relationship, were generally accepted based on customer and quality orientation, quality information, and leadership. Firm performance was measured through growth, profitability, new product success, and changes in market share. Previously, different performance criteria were used to measure competitiveness, productivity, and efficiency of firms. Quantitative firm performance measures comprise financial, marketing, innovative, and production performances. The questions regarding firm performance were asked embedding a 5 -point Likert scale in which 1 refers to extremely unsuccessful, 2 refers to unsuccessful, 3 refers to similar, 4 refers to successful, and 5 refers to extremely successful. 


\subsection{Data collection}

The data was collected using a structured questionnaire developed and distributed to employees of Jordanian insurance companies. Initially, the questionnaire was constructed and distributed in Arabic and was translated into English later. Pearson correlation coefficient between each item and related dimensions was calculated to construct validity. The computed values were above 0.70 , which showed a strong positive relationship.

\subsection{Statistical analysis}

The one-dimensionality of six variables, including 10 items, was assessed using confirmatory factor analysis. The measurement model provided a reasonable fit to the data. The fit indices throughout the acceptable range were conventionally reported. The reliability of constructs was measured using a composite reliability index and average variance extracted index. Both indices were measured to be 0.6 and 0.5 , respectively, which was relatively higher than the assessment criteria of average variance extracted for all the measures. Partial least square structural equation modeling (PLSSEM) was used to analyze the data collected using SmartPLS version 3.2.8. Moreover, due to complex and exploratory modeling framework with multiple theoretical diffusions, it is appropriate to employ PLS-SEM.

\section{RESULTS}

The first part of the questionnaire form has been designed to collect respondents' demographics-related data. Table 1 shows frequencies and percentages for gender, years of experience, and qualification variables. Findings revealed that $82.16 \%$ of the participants were male and $17.84 \%$ were female. $45.61 \%$ of the participants had 2 to 3 years of work experience, and $36.8 \%$ of the participants had 3 to 4 years of experience. Most of the participants (46.19\%) had Bachelor's degree (46.19\%), while $33.62 \%$ had Master's degree. Table 2 presents correlation analysis between the variables. The majority of the variables showed strong and positive correlation.

In Table 3, all the variables have greater AVE coefficient as compared to recommended $50 \%$, and higher composite reliability as compared to the $70 \%$ threshold. The findings have achieved better convergent validity in terms of the recommended thresholds.

Table 1. Descriptive statistics ( $n=342)$

\begin{tabular}{|c|c|c|c|}
\hline \multicolumn{2}{|c|}{ Demographic } & \multirow{2}{*}{$\frac{\text { Frequency }}{281}$} & \multirow{2}{*}{ Percent } \\
\hline Gender & Male & & \\
\hline Geriuet & Female & 61 & 17.84 \\
\hline \multirow{3}{*}{ Years of experience } & 1 to 2 years & 60 & 17.5 \\
\hline & 2 to 3 years & 156 & 45.61 \\
\hline & 3 to 4 years & 126 & 36.8 \\
\hline \multirow{3}{*}{ Qualification } & Bachelors & 158 & 46.19 \\
\hline & Masters & 115 & 33.62 \\
\hline & Post-graduate & 69 & 20.17 \\
\hline
\end{tabular}

Table 2. Correlation analysis

\begin{tabular}{|c|c|c|c|c|c|c|c|}
\hline Constructs & Teamwork & Staffing & $\begin{array}{l}\text { Training and } \\
\text { development }\end{array}$ & $\begin{array}{c}\text { Performance } \\
\text { appraisals }\end{array}$ & Compensation & TQM & Performance \\
\hline Teamwork & 1 & & & & & & \\
\hline Staffing & 0.172 & 1 & & & & & \\
\hline $\begin{array}{l}\text { Training and } \\
\text { development }\end{array}$ & 0.075 & 0.761 & 1 & & & & \\
\hline $\begin{array}{l}\text { Performance } \\
\text { appraisals }\end{array}$ & 0.240 & 0.161 & 0.097 & 1 & & & \\
\hline Compensation & 0.085 & 0.747 & 0.834 & 0.045 & 1 & & \\
\hline TQM & 0.087 & 0.774 & 0.915 & 0.061 & 0.872 & 1 & \\
\hline Performance & 0.234 & 0.675 & 0.567 & 0.111 & 0.876 & 0.654 & 1 \\
\hline
\end{tabular}


Table 3. Convergent validity

\begin{tabular}{l|c|c}
\hline \multicolumn{1}{c|}{ Constructs } & Composite reliability & Average variance extracted (AVE) \\
\hline Teamwork & 0.823 & 0.700 \\
Staffing & 0.808 & 0.585 \\
\hline Training and development & 0.808 & 0.685 \\
\hline Performance appraisals & 0.917 & 0.734 \\
\hline Compensation & 0.860 & 0.673 \\
\hline TQM & 0.903 & 0.699 \\
\hline Performance & 0.830 & 0.622 \\
\hline
\end{tabular}

Table 4. Fornell and Larcker (1981) criterion

\begin{tabular}{|c|c|c|c|c|c|c|c|}
\hline Constructs & TA & STAFF & T\&D & PA & COM & TQM & PER \\
\hline Teamwork & 0.84 & & & & & & \\
\hline Staffing & -0.34 & 0.77 & & & & & \\
\hline Training and development & 0.29 & -0.15 & 0.83 & & & & \\
\hline Performance appraisals & -0.11 & 0.30 & 0.01 & 0.86 & & & \\
\hline Compensation & -0.08 & -0.05 & 0.13 & 0.21 & 0.82 & & \\
\hline TQM & -0.07 & 0.36 & 0.20 & 0.57 & 0.21 & 0.84 & \\
\hline Performance & 0.30 & 0.07 & 0.06 & 0.19 & 0.18 & 0.14 & 0.79 \\
\hline
\end{tabular}

Table 4 shows the Fornell and Larcker (1981) criterion for each construct. As per the standard, squared-root of each construct should be higher than its cross-sectional correlation coefficients of other constructs. As proposed by Fornell and Larcker (1981), the constructs shown in Table 4 have accomplished discriminant validity.

Table 5 shows that path analysis confirms the impact of HRM determinants on TQM and employee performance. The results indicated a significant and positive effect of teamwork, staff- ing, performance appraisals, and compensation on TQM. However, training and development negatively but significantly affects TQM. In addition, TQM significantly and positively affects the HRM of an organization. Performance was also positively and significantly affected by TQM (Table 5).

Table 6 presents that two reflective constructs of HRM, namely, teamwork and performance appraisals, have $52 \%$ and $77 \%$ predictive relevance. However, three reflective constructs of HRM,

Table 5. Path analysis

\begin{tabular}{|c|c|c|c|c|}
\hline Path & Estimate & S.D. & $T$-stats & Prob. \\
\hline Teamwork $\rightarrow$ TQM & 0.13 & 0.07 & 1.82 & 0.04 \\
\hline Staffing $\rightarrow$ TQM & 0.35 & 0.05 & 6.74 & 0.00 \\
\hline Training and development $\rightarrow$ TQM & -0.20 & 0.07 & 2.80 & 0.00 \\
\hline Performance appraisals $\rightarrow$ TQM & 0.15 & 0.06 & 2.38 & 0.01 \\
\hline Compensation $\rightarrow$ TQM & 0.19 & 0.07 & 2.56 & 0.01 \\
\hline $\mathrm{TQM} \rightarrow \mathrm{HRM}$ & 0.32 & 0.05 & 4.51 & 0.03 \\
\hline TQM $\rightarrow$ Performance & 0.45 & 0.06 & 5.61 & 0.02 \\
\hline
\end{tabular}

Table 6. Predictive relevancy

\begin{tabular}{l|c|c|c}
\hline \multicolumn{1}{c}{ Endogenous variables } & R Square & R Square adjusted & Q Square \\
\hline Teamwork & 0.52 & 0.52 & 0.34 \\
\hline Staffing & 0.09 & 0.07 & 0.04 \\
\hline Training and development & 0.13 & 0.12 & 0.76 \\
Performance appraisals & 0.77 & 0.16 & 0.55 \\
Compensation & 0.17 & 0.75 & 0.10 \\
\hline TQM & 0.75 & 0.52 \\
\hline
\end{tabular}


including staffing, training and development, and compensation, have the predictive relevancy of $9 \%, 13 \%$, and $17 \%$, respectively. TQM shows a predictive relevancy of $75 \%$ toward performance construct (Table 6).

\section{DISCUSSION}

There is a significant positive impact of teamwork on TQM, since the leaders in insurance companies assumed teamwork culture and the safety climate more strongly as compared to the frontline staff, and thus, $\mathrm{H} 1$ is accepted. The study results confirm that the management system currently implemented plays an important role in improving competitive culture of quality orientation. This finding was supported by Wang et al. (2019) who indicated that the leaders fulfilled their objectives by implementing supporting measures during daily work tasks, and to provide a competitive culture. Therefore, it is stated that employee involvement and employee empowerment with the people criterion and quality orientation in insurance companies in Jordan are significantly related. Pambreni et al. (2019) have asserted that the companies are positively oriented at implementing the employee involvement programs to improve organizational performance, competitiveness, and growth on both local and global market. The potential of the top management is mostly oriented toward TQM for creating an environment of participation, sharing, and teamwork. It is the potential for sharing the decision between top management and faculty members for confirming that all members are aware of and get the information accurately (El Hawiand \& Alzyadat, 2019).

There is a significant positive impact of staffing on TQM in Jordanian insurance companies; thus, $\mathrm{H} 2$ is accepted. This is because the improvement of employees' skills enhances cost of products and quality through the efficient use of materials and machines and mitigation of wastages. Quality circle is a promising example, which allows the employees to be aware of the need to enhance the quality of work. In this regard, people criterion is focused on the engagement of employees in enhancing the quality of work using TQM. According to Anil and Satish
(2019), TQM is planned by the top managers, but the input of middle levels and lower levels must be accounted into support before launching the TQM. In particular, employee performance is enhanced by TQM practices based on continuous improvement, employee participation, leadership and process management, and customer focus (Saffarand \& Obeidat, 2020).

There is a significant impact of training and development on TQM in insurance companies of Jordan because of developing and enriching preferable attitude of employees; thus, $\mathrm{H} 3$ is accepted. Therefore, organizations need to launch influential training programs to reap the reimbursement of preferable attitudinal consequences. This finding is supported by $\mathrm{Al}$ Qudah et al. (2018) who asserted that transformational training programs were positively and significantly related to employee loyalty. Furthermore, advantages of training programs are twofold as this positively affects employee attitudes and improves knowledge and skill sets of employees. Similar results were presented by Faridi et al. (2017) who indicated that providing training opportunities to employees make them feel that the organization is concerned about them. This approach is likely to escalate levels of satisfaction and loyalty among the employees towards the company. Training and development have a positive impact on the level of satisfaction and motivation among the trainees (Samwel, 2018). The investment of organizations is huge in employee training programs for enhancing employee abilities, which consequently enhances employee performance. It is complicated to realize that organizations will continue to make such investments if training programs produced minimal in the way of performance enhancement. There will be significant effects on job performance as employees learn the job and advance through different stages of skill acquisition.

There is a significant positive impact of performance appraisals on TQM in insurance companies, thus, H4 is accepted. Competition between employees is promoted by performance appraisal systems. These findings suggest that performance appraisal programs can be launched for developing significant measures associated with teamwork behavior and group performance 
consequences, even though there are arguments to incorporate individual-oriented appraisals in a performance management system (Soltani \& Wilkinson, 2018). For example, group performance norms, individual outliers, and social loafers can be identified through the performance distributions of individual team members. In this regard, the performance appraisals assessment system can be planned for stressing the significance of both employee cooperation and performance quality (Imran et al., 2018).

Practitioners and researchers have shown an interest in TQM and HRM, since HRM is essential to success; although organizations initially emphasize a production-oriented quality perspective (Idris, 2011). It is a fact that the enhancement in organizational performance in relation to TQM is mainly due to HRM, culture, customer orientation, and leadership that are included in the soft dimensions of TQM (Singh et al. 2011); thus, H5 is accepted. This study has proved that the effectiveness of HRM can change empowerment and management style of people. In this context, TQM and HRM can be associated due to their combined complementary contributions (Youssef et al. 2014). This study has explored the connection between TQM and HRM and showed the significance of HR with implementing TQM program, and thus, $\mathrm{H} 6$ is accepted. In addition, the study showed that workforce had a significant impact on total quality and overall success of the organization, which suggests that the management of people and considering their level of satisfaction are important aspects.

It has been observed that HRM practices must be managed with respect to TQM principles. On the contrary, a literature-derived model is presented showing the significant HRM practices that guide employees to maintain TQM (CalvoMora et al., 2014). In this context, advancement in the association between HRM and TQM using a methodology offers statistical generalization, with the major focus on all the HRM practices, rather than considering each practice independently. The findings have allowed supporting company business strategies by establishing action plans. A culture that maintains TQM should be promoted by personnel practic- es to assure significant contribution of HRM to the organizational performance (H7).

\section{PRACTICAL AND THEORETICAL IMPLICATIONS}

The findings have further confirmed that TQM is considered as an effective approach to increase competitiveness among enterprises. TQM makes efforts using the continual enhancement of the quality of its people, procedures, environments, and services to increase the competitiveness of an organization. Moreover, company reputation is benefited by integrating TQM as it enhances the quality awareness and increases the level of satisfaction among the employees.

This study is important because it bridges existing gaps, as previous studies have failed to investigate the impact of HRM on TQM. This gap was important to be filled as it improves the understanding of HRM practices and its impact on TQM through people criterion and quality criterion aspects. This study has also highlighted the significance of the insurance sector that is considered as an important pillar of the country's development. Furthermore, this study makes efforts in enriching the studies of TQM by identifying HRM as an essential aspect in enriching the organizational performance.

The study findings also offer significant managerial implications, specifically for the insurance sector. For instance, practitioners and researchers must acknowledge the role of HRM in maintaining longterm quality management. However, there is a need to change conventional HRM practices that conflict with TQM. Thereby, HRM function should lead activities such as designing of teams and jobs that empower cooperation, promote employees for providing information, select employees, and improve training and development programs. Effective relationship between HRM and TQM can provide better organizational consequences. A company's performance can be increased if quality policies are associated with HR like creating and communicating the TQM vision, generating quality awareness among employees, and preparing an organization and employees for TQM implementation. 


\section{CONCLUSION}

The study concludes that quality orientation is improved in light of HRM practices with the implementation of TQM in Jordanian insurance companies. The contribution of HRM systems can help organizations to sustain competitive advantage as it allows developing organizational resources and capabilities. Similarly, organizational learning and innovation are important in achieving the sustainable advantage. Therefore, strategic perspective of HRM covers all the HR strategies adopted by companies and attempts to estimate their effects on performance.

The study has indicated a significant and positive effect of teamwork, staffing, performance appraisals, and compensation on TQM. However, training and development negatively but significantly affects TQM. In addition, TQM significantly and positively affects the HRM of an organization. Performance was also positively and significantly affected by HRM.

The selection of a TQM program was positively associated with HRM practices such as training and development, employee teamwork, appraisal and compensation practices, and empowerment. Furthermore, a work climate with trust, accountability for goal achievement, and employee involvement can be formed through TQM enhancement efforts that bring positive change in organizational culture. Organizations should be careful about the isolated implementation of TQM - it is a holistic philosophy that involves all organizational stakeholders, with high individual content.

\section{FUTURE RESEARCH}

Several recommendations are made to bridge the gaps in the present research, in response to the limitations of this study. Despite being a large-scale study, it also has limitations and therefore contributes to some recommendations for future research. Researchers interested in studying organizational management should focus on comparative research design. This can help to understand the difference between private and public sectors with respect to HRM and TQM and their interrelationships between different regions of Jordan. This may offer a better insight of TQM and its integration into the culture of the Middle East, especially in the financial insurance sector. It is also suggested that researchers can investigate a different activity regardless of organizational performance.

\section{AUTHOR CONTRIBUTIONS}

Conceptualization: Naser Khdour, Ahmad Samed Al-Adwan, Jamal Ahmed Al-Douri, Anas AlSoud. Data curation: Naser Khdour, Ahmad Samed Al-Adwan, Jamal Ahmed Al-Douri.

Formal analysis: Jamal Ahmed Al-Douri.

Methodology: Naser Khdour, Ahmad Samed Al-Adwan, Jamal Ahmed Al-Douri, Anas AlSoud. Project administration: Naser Khdour, Ahmad Samed Al-Adwan, Jamal Ahmed Al-Douri, Anas AlSoud.

Writing - original draft: Naser Khdour, Ahmad Samed Al-Adwan, Jamal Ahmed Al-Douri, Anas AlSoud.

Writing - review \& editing: Naser Khdour, Ahmad Samed Al-Adwan, Jamal Ahmed Al-Douri, Anas AlSoud.

\section{ACKNOWLEDGMENT}

The authors are very thankful to all the associated personnel in any reference that contributed to the purpose of this study. 


\section{REFERENCES}

1. Al Qudah, N. F., Yang, Y., \& Anjum, M. A. (2018). Transformational Training Programs and Quality Orientation of Employees: Does Employees' Loyalty Matter? Sustainability, 10(2), 465. https://doi.org/10.3390/ su10020465

2. Albuhisi, A. M., \& Abdallah, A. B. (2018). The impact of soft TQM on financial performance. International Journal of Quality \& Reliability Management. https://doi.org/10.1108/ ijqrm-03-2017-0036

3. Androniceanu, A. (2017). The three-dimensional approach of Total Quality Management, an essential strategic option for business excellence. Amfiteatru Economic, 19(44), 61-78. https://www.econstor.eu/handle/10419/169057

4. Anil, A. P., \& Satish, K. P. (2019). TQM practices and its performance effects-an integrated model. International Journal of Quality \& Reliability Management. https://doi.org/10.1108/ ijqrm-10-2018-0266

5. Arunachalam, S., Zwet, A., \& Snailum, N. (2018). TQM Model for Manufacturing SMEs in the Middle East. i-Manager's Journal on Management, 12(4), 32. https:// doi.org/10.26634/jmgt.12.4.14526

6. Balasubramaniam, S., \& Farooqui, S. (2017). TQM and Role of HR in its Implementation MCCIA860.

7. Berman, E. M., Bowman, J. S., West, J. P., \& Van Wart, M. R. (2019). Human resource management in public service: Paradoxes, processes, and problems. CQ Press.

8. Calvo-Mora, A., Picón, A., Ruiz, C., \& Cauzo, L. (2014). The relationships between soft-hard TQM factors and key business results. International Journal of Operations \& Production Management. https://doi. org/10.1108/ijopm-09-2012-0355

9. Cao, G., Clarke, S., \& Lehaney, B. (2000). A systemic view of organizational change and TQM.
The TQM magazine. https://doi. org/10.1108/09544780010320241

10. Chandler, G. N., \& McEvoy, G. M. (2000). Human resource management, TQM, and firm performance in small and medium-size enterprises. Entrepreneurship Theory and Practice, 25(1), 43-58. https://doi.org/10.1177\% 2F104225870002500105

11. Chang, Chih C., Chiu, C. M., \& Chen, C. A. (2010). The effect of TQM practices on employee satisfaction and loyalty in government. Total Quality Management, 21, 1299-1314. https://doi.org/10.1080/14783363. 2010.530796

12. Chukwulozie, O., Nnaemeka, O. E., \& Chigoziri, N. I. (2018). Quality and Productivity Management. In Proceedings of the World Congress on Engineering and Computer Science 2.

13. El Hawi, R., \& Alzyadat, W. (2019). TQM Measured Students' Satisfaction in the Jordanians' Private University for Achieving Institutional Excellence. TEM Journal, 8(2), 409. https://www. temjournal.com/content/82/TEMJournalMay2019_409_416.pdf

14. Faridi, A., Baloch, A., \& Wajidi, A. (2017). The mediating role of job satisfaction between training and development practices and organizational commitment: responses from private banking sectors of Karachi, Pakistan. https://doi.org/10.6007/ijarbss/ v7-i10/3415

15. Fornell, C., \& Larcker, D. F. (1981). Structural equation models with unobservable variables and measurement error: Algebra and statistics. https://doi. org/10.2307/3150980

16. Gupta, V., Kumar, R., \& Garg, D. (2017). Efficacy appraisal model of TQM elements in auto industry in India. International Journal of Services and Operations Management, 26(1), 122-140. https://doi.org/10.1504/ijsom.2017.080680
17. Hart, C., \& Schlesinger, L. (1991). Total quality management and the human resource professional: applying the Baldrige framework to human resources. Human Resource Management, 30(4), 433-454. https://doi.org/10.1002/ hrm.3930300402

18. Hinterhuber, A., \& Liozu, S. M. (2014). Is innovation in pricing your next source of competitive advantage? Business Horizons, 57(3), 413-423. https://doi. org/10.4324/9781315184845-2

19. Idris, F. (2011). Total Quality Management (TQM) and sustainable company performances: Examining the relationship in Malaysian firms. International Journal of Business \& Society, 12(1). https://www.researchgate. net/publication/286004034_Total_quality_management_TQM_ and_sustainable_company_performances_Examining_the_relationship_in_Malaysian_firms

20. Imran, M., Haque, A. U., \& Rębilas, R. (2018). Performance appraisal politics and employees' performance in distinctive economies. Polish Journal of Management Studies, 18. https://doi. org/10.17512/pjms.2018.18.2.11

21. James, P. (2017). Total quality environmental management and human resource management. In Greening People (pp. 35-48). Routledge. https://doi.org/10.9774/ gleaf.978-1-909493-00-1_3

22. Jung, J. Y., Wang, Y. J., \& Wu, S. (2009). Competitive strategy, TQM practice, and continuous improvement of international project management. International Journal of Quality \& Reliability Management. https://doi. org/10.1108/02656710910928806

23. Kafetzopoulos, D., Gotzamani, K., \& Gkana, V. (2015). Relationship between quality management, innovation and competitiveness. Evidence from Greek companies. Journal of Manufacturing Technology Management. https:// doi.org/10.1108/jmtm-02-20150007 
24. Khanam, S, Siddiqui, J., \& Talib, F. (2013). Role of Information Technology in Total Quality Management: A Literature Review. International Journal of Advanced Research in Computer Engineering and Technology, 2(8), 2433-2445.

Retrieved from https://papers.ssrn. com/sol3/papers.cfm?abstract_ $\mathrm{id}=2725096$

25. Koh, H. C., Sim, K. L., \& Killough, L. N. (2004). The interaction effects of lean production manufacturing practices, compensation, and information systems on production costs: a recursive partitioning model. Advances in Management Accounting, 12, 115-135. https:// www.researchgate.net/publication/235318447_THE_INTERACTION_EFFECTS_OF_LEAN_ PRODUCTION_MANUFACTURING_PRACTICES_COMPENSATION_AND_INFORMATION_SYSTEMS_ON_PRODUCTION_COSTS_A_RECURSIVE_ PARTITIONING_MODEL

26. Kumar, V., \& Pansari, A. (2016). Competitive advantage through engagement. Journal of Marketing Research, 53(4), 497-514. https:// doi.org/10.1509/jmr.15.0044

27. Lamine, K., \& Lakhal, L. (2018). Impact of TQM/Six Sigma practices on company's performance: Tunisian context. International Journal of Quality \& Reliability Management. https://doi.org/10.1108/ ijqrm-05-2017-0097

28. Lee, J. S., Back, K. J., \& Chan, E. S. (2015). Quality of work life and job satisfaction among frontline hotel employees. International Journal of Contemporary Hospitality Management. https://doi.org/10.1108/ ijchm-11-2013-0530

29. Liu, Y., Yu, Y., Zeng, Z., \& Zhang, Y. (2018, August). Study on Construction of Performance Appraisal System for Railway Grass-roots Units Based on TQM. In 2018 2nd International Conference on Education Science and Economic Management (ICESEM 2018). Atlantis Press.

30. Madanat, H. G., \& Khasawneh, A. S. (2017). Impact of total quality management implementation on effectiveness of human resource management in the Jordanian banking sector from employees' perspective. Academy of Strategic Management Journal, 16(1). https://www.abacademies.org/ articles/impact-of-total-qualitymanagement-implementation-oneffectiveness-of-human-resourcemanagement-in-the-jordanianbanking-sector-fr-6526.html

31. Madanat, H. G., \& Khasawneh, A. S. (2018). Level of effectiveness of human resource management practices and its impact on employees' satisfaction in the banking sector of Jordan. Journal of Organizational Culture, Communications and Conflict, 22(1), 1-19. https://www. abacademies.org/articles/level-ofeffectiveness-of-human-resourcemanagement-practices-and-itsimpact-on-employees-satisfactionin-the-banking-sector-of-jo-7120. html

32. Mahmutaj, L. R., Jusufi, G., Zylfijaj, K., \& Grubi, A. K. (2015). The role of quality management practices in improving the efficiency and effectiveness of financial services. Mediterranean Journal of Social Sciences, 6(2 S5), 218.

33. Manafi, M., \& Subramaniam, I. D. (2015). The role of the perceived justice in the relationship between human resource management practices and knowledge sharing: A study of Malaysian universities lecturers. Asian Social Science, 11(12), 131. https://www. mcser.org/journal/index.php/mjss/ article/view/6182/0

34. Manhas, V. K., Gupta, P., \& Gupta, H. (2015). Developing and validating critical success factors of TQM implementation in MSMEs of Punjab in India. International Journal of Indian Culture and Business Management, 11(4), 405421. https://ideas.repec.org/a/ids/ ijicbm/v11y2015i4p405-421.html

35. Masa'deh, R., Dmaithan A. A., Ala’aldinA., \& Bader O. (2019). The Role of Knowledge Management Infrastructure in Enhancing Job Satisfaction: A Developing Country Perspective. Interdisciplinary Journal of
Information, Knowledge \& Management, 14, 001-025. https://www.researchgate.net/ publication/330279605_The_ Role_of_Knowledge_Management_Infrastructure_in_Enhancing_Job_Satisfaction_A_Developing_Country_Perspective

36. Masum, A. K. M., Beh, L. S., Azad, M. A. K., \& Hoque, K. (2018). Intelligent human resource information system (i-HRIS): a holistic decision support framework for HR excellence. The International Arab Journal of Information Technology, 15(1), 121-130. https://iajit.org/PDF/ January\%202018,\%20No.\%20 1/9605.pdf

37. Mwalim, A. O., Robert K. W. E., \& MrKwendo E. (2019). Effect of Setting of Performance Contract Objectives on Organizational Performance in the State-Owned Sugar Companies. International. Journal of Multidisciplinary and Current Research, 7. http://ijmcr. com/effect-of-setting-of-performance-contract-objectives-on-organizational-performance-in-thestate-owned-sugar-companies/

38. Nirmala, B. P., \& Faisal, A. M. (2016). A literature review of TQM and HRM for identification of appropriate critical success factors (CSFs). International Journal of Applied Research, 2(7), 742-745. https://www.semanticscholar.org/ paper/A-literature-review-ofTQM-and-HRM-for-of-criticalNirmala-Faisal/37b5322578c22f10 81ece534a675774c4c22b86e

39. Obeidat, B. Y., Hadeel, F. T., \& Ra'edMasadeh. (2018). The Relationship between Human Resource Management HRM Practices, Total Quality Management TQM Practices and Competitive Advantages. Modern Applied Science, 12(11).

40. Pambreni, Y., Khatibi, A., Azam, S., \& Tham, J. (2019). The influence of total quality management toward organization performance. Management Science Letters, 9(9), 1397-1406. http://growingscience. com/beta/msl/3218-the-influenceof-total-quality-managementtoward-organization-performance. html 
41. Perdomo-Ortiz, J., GonzalezBenito, J., \& Galende, J. (2009). An analysis of the relationship between total quality management-based human resource management practices and innovation. The International Journal of Human Resource Management, 20(5), 1191-1218. https://doi. org/10.1080/09585190902850372

42. Qasrawi, B. T., Almahamid, S. M., \& Qasrawi, S. T. (2017). The impact of TQM practices and $\mathrm{KM}$ processes on organisational performance an empirical investigation. International Journal of Quality \& Reliability Management, 34(7), 10341055. https://doi.org/10.1108/ ijqrm-11-2015-0160

43. Ruiz, E., Sánchez de Pablo, J. D., Muñoz, R. M., \& Peña, I. (2019). Do high performance work systems enhance business performance? Examining the mediating influence of total quality management. Zbornik radova Ekonomskog fakulteta u Rijeci: časopis za ekonomsku teoriju $i$ praksu, 37(1), 235-258. https://doi. org/10.18045/zbefri.2019.1.235

44. Saffar, N., \& Obeidat, A. (2020). The effect of total quality management practices on employee performance: The moderating role of knowledge sharing. Management Science Letters, 10(1), 77-90. https://doi. org/10.5267/j.msl.2019.8.014

45. Sainis, G., Haritos, G., Kriemadis, T., \& Fowler, M. (2017). The quality journey for Greek SMEs and their financial performance. Production \& Manufacturing Research, 5(1), 306-327. https:// doi.org/10.1080/21693277.2017.1 374891

46. Samwel, J. O. (2018). Impact of employee training on organizational performance case study of drilling companies in Geita, Shinyanga and Mara regions in Tanzania. International Journal of Management Studies and Research, 6(1). https://doi. org/10.20431/2349-0349.0601005

47. Singh, K., \& Ahuja, I. S. (2015). An evaluation of transfusion of TQM-TPM implementation initiative in an Indian manufacturing industry. Journal of Quality in Maintenance Engineering. https://doi. org/10.1108/jqme-04-2013-0017

48. Singh, T., Geetika, G., \& Dubey, R. (2011). A theoretical framework for soft dimensions of total quality management. In International conference on economics and finance research IPEDR (Vol. 4).

49. Soltani, E., \& Wilkinson, A. (2020). TQM and performance appraisal: complementary or incompatible? European Management Review, 17(1), 57-82. https://doi. org/10.1111/emre.12317

50. Tiamaz, Y., \& Souissi, N. (2018, April). Classification of the lean implementation procedures for improving the business processes. In 2018 International Conference on Intelligent Systems and Computer Vision (ISCV) (pp. 1-6). IEEE. https://doi.org/10.1109/ isacv.2018.8354019

51. Ullah, Ph., (2017). Collaborative leadership in financial services. Routledge.

52. Vaish, A., Vaish, A., Vaishya, R., \& Bhawal, S. (2016). Customer relationship management (CRM) towards service orientation in hospitals: A review. Apollo Medicine, 13(4), 224-228. https://doi.org/10.1016/j. apme.2016.11.002

53. Vivares-Vergara, J. A., William, A. S., \& Julia C. N. (2016). Impact of human resource management on performance in competitive priorities. International Journal of Operations and Production Management, 36,114-134. https://doi.org/10.1108/ ijopm-11-2013-0484

54. Wang, K. Y., Chou, C. C., \& Lai, J. C. Y. (2019). A structural model of total quality management, work values, job satisfaction and patient-safety-culture attitude among nurses. Journal of Nursing Management, 27(2), 225-232. https://doi.org/10.1111/ jonm.12669

55. Wickramasinghe, V. (2012). Influence of total quality management on human resource management practices. International Journal of Quality \& Reliability Management. https://doi. org/10.1108/02656711211270324

56. Yang, C. C. (2006). The impact of human resource management practices on the implementation of total quality management. The TQM Magazine. https://doi. org/10.1108/09544780610647874

57. Youssef, E. M., Youssef, M. A., \& Ahmed, A. M. M. (2014). Total quality management intensity and its impact on HRM practices in manufacturing firms. International Journal of Productivity and Quality Management, 13(4), 495-512. https://doi.org/10.1504/ ijpqm.2014.062224 